\title{
Mesembrinellinae (Diptera: Calliphoridae) to edge effects in the Tinguá Biological Reserve, Rio de Janeiro, Brazil
}

\author{
B. Q. Gadelha ${ }^{a *}$, A. B. Silva ${ }^{a}$, A. C. P. Ferraz $a$ and V. M. Aguiar ${ }^{a, b}$ \\ ${ }^{a}$ Laboratório de Estudo de Dípteros, Departamento de Microbiologia e Parasitologia, Universidade Federal do \\ Estado do Rio de Janeiro - UNIRIO, Rua Frei Caneca, 94, Centro, CEP 20211-040, Rio de Janeiro, RJ, Brasil \\ bPrograma Pós-graduação em Ciências Biológicas (Biodiversidade Neotropical), Universidade Federal do \\ Estado do Rio de Janeiro - UNIRIO, Avenida Pasteur, 458, Urca, CEP 22290-240, Rio de Janeiro, RJ, Brasil \\ *e-mail:barbara.gadelha@ymail.com
}

Received: May 26, 2014 - Accepted: September 6, 2014 - Distributed: November 30, 2015

(With 5 figures)

\begin{abstract}
In this study we describe the diversity of Mesembrinelinae in a biological reserve in the city of Nova Iguaçu, State of Rio de Janeiro. Traps containing sardines were distributed seasonally, at four sites: Site A ( $\left.22^{\circ} 58.788^{\prime} \mathrm{S}, 43^{\circ} 43.459^{\prime} \mathrm{W}\right)$, in a forest edge, and sites $\mathrm{B}\left(22^{\circ} 58.523^{\prime} \mathrm{S}, 43^{\circ} 44.540^{\prime} \mathrm{W}\right), \mathrm{C}\left(22^{\circ} 58.350^{\prime} \mathrm{S}, 43^{\circ} 44.678^{\prime} \mathrm{W}\right)$, and $\mathrm{D}\left(22^{\circ} 34.865^{\prime} \mathrm{S}\right.$, $43^{\circ} 27.063^{\prime} \mathrm{W}$ ), located $1,000 \mathrm{~m}, 500 \mathrm{~m}$, and $2,000 \mathrm{~m}$ respectively, inwards from the edge. A total of 2,150 individuals of Mesembrinellinae were collected, representing ten species. Laneela nigripes Guimarães, 1977 was the most abundant species, followed by Mesembrinella bellardiana Aldrich, 1922, Eumesembrinella cyaneicincta (Surcouf, 1919) and Mesembrinella semihyalina Mello, 1967. These species were common and constant during the study period. Mesembrinella batesi Aldrich, 1922, Eumesembrinella quadrilineata (Fabricius, 1805) and Huascaromusca aeneiventris (Wiedmann, 1830) were the less abundant flies, being considered rare and accidental. Eumesembrinella besnoiti (Seguy, 1925) was rare and accessory. Eumesembrinella cyaneicincta, M. bellardiana, M. semihyalina and M. bicolor were mostly collected in site B, while L. nigripes was mostly collected in site C. The edge effect was not evident since the four sites showed similar populations. Site B showed a strong positive relationship between abundance and richness, in site $\mathrm{C}$ the correlation was positive and weak, and there was no correlation in A and D. The highest abundance of specimens was recorded during autumn and winter. These flies occurred from the edge up to 2,000m inside the forest.
\end{abstract}

Keywords: blowflies, asynanthropic species, biodiversity, conservation, Atlantic Rain Forest.

\section{Mesembrinellinae (Diptera: Calliphoridae) na Reserva Biológica do Tinguá, Rio de Janeiro, Brasil}

\section{Resumo}

Nesse estudo, descrevemos a diversidade de Mesembrinelinae, em uma reserva biológica na cidade de Nova Iguaçu, Estado do Rio de Janeiro. Armadilhas contendo sardinha foram distribuídas sazonalmente em quatro pontos: Ponto A $\left(22^{\circ} 58.788^{\prime} \mathrm{S}, 43^{\circ} 43.459^{\prime} \mathrm{W}\right)$, na borda da mata B ( $\left.22^{\circ} 58.523^{\prime} \mathrm{S}, 43^{\circ} 44.540^{\prime} \mathrm{W}\right), \mathrm{C}\left(22^{\circ} 58.350^{\prime} \mathrm{S}, 43^{\circ} 44.678^{\prime} \mathrm{W}\right)$, e D $\left(22^{\circ} 34.865^{\prime} \mathrm{S}, 43^{\circ} 27.063^{\prime} \mathrm{W}\right)$, localizados a $1.000 \mathrm{~m}, 500 \mathrm{~m}$ e $2.000 \mathrm{~m}$ para o interior da borda respectivamente. Foram coletados 2.159 exemplares de Mesembrinellinae, com um total de dez espécies. Laneela nigripes Guimarães, 1977 foi a espécie mais abundante, seguida por Mesembrinella bellardiana Aldrich, 1922, Eumesembrinella cyaneicincta (Surcouf, 1919) e Mesembrinella semihyalina Mello, 1967. Essas espécies foram consideradas comuns e contantes durante o período de estudo. Mesembrinella batesi Aldrich, 1922, Eumesembrinella quadrilineata Fabricius, 1805 e Huascaromusca aeneiventris (Wiedmann, 1830) foram as moscas com as menores abundâncias, sendo consideradas raras e acidentais, Eumesembrinella besnoiti (Seguy, 1925) foi rara e acessória. Eumesembrinella cyaneicincta, M. bellardiana, M. semihyalina e M. bicolor foram as mais coletadas no ponto B, enquanto L. nigripes foi a mais coletada no ponto C. Os efeitos de borda não foram evidentes porque os quatro pontos apresentaram populações similares. O ponto B apresentou uma relação forte e positiva entre a abundância e a riqueza, no ponto $\mathrm{C}$ a correlação foi positiva e fraca e não houve correlação nos pontos A e D. A maior abundância de indivíduos foi registrada nas estações do outono e inverno. Espécimes da subfamília Mesembrinellinae ocorreram da borda até 2.000 metros para o interior da mata.

Palavras-chave: califorídeos, espécies assinantrópicas, biodiversidade, conservação, Mata Atlântica. 


\section{Introduction}

Species of plants and animals are adapted to certain temperature, humidity, and light levels, and therefore, according to Ferraz et al. (2010a), many species living in forest fragments may disappear if these factors change. Loss of area can immediately eliminate some species that are rare or have patchy distribution. One of the factors related to habitat modification by humans and that affects more than one fragment is the edge effect, which was defined by Forman and Gordon (1986) as a change in structure, composition, and/or relative abundance of species in the border of a fragment.

Insects can act as indicators of human interference in natural environments (Martos and Maia, 1997), because of their small size and susceptibility to environmental variations. We highlighted the Mesembrinellinae as a potentially useful group to indicate the degree of environmental preservation, since their distribution is restricted to forests in protected environments (Gadelha et al., 2009; Cabrini et al., 2013).

Many species of flies are typical of forested regions such as the Tinguá Biological Reserve, as we have noted previously (Ferraz et al., 2009). The population dynamics of species have changed due to anthropogenic factors such as deforestation and the introduction of exotic species (D'Almeida and Lopes, 1983). Marinho et al. (2006) suggested that human activities may have affected the fauna distribution of Calliphoridae in the Tinguá Biological Reserve. Some synanthropic species of Calliphoridae have shifted toward the interior of the reserve (Ferraz et al., 2009).

The calliphorid flies comprise a heterogenous family found in all zoogeographical regions, with over 1,000 species and 150 genera described. Greenberg and Szyska (1984) considered that this family consists of colonizing species as they have high dispersal ability, are capable of locating ephemeral resources over long distances, and present diverse food habits (Prado and Guimarães, 1982; Silva et al., 2012).

Kutty et al. (2010) considered that the phylogenetic relationships within this insect radiation are very poorly understood and controversial. They proposed a higher-level phylogenetic hypothesis for the Calyptratae based on an extensive DNA sequence, and within the Oestroidea they confirmed with molecular data that the Calliphoridae are a paraphyletic grade of lineages. This corroborates Rognes (2005) who considered that the Calliphoridae (Blowflies) are not a monophyletic group.

A literature revision revealed that all species of Calliphoridae found in the Americas south of Mexico between the years of 1960 and 2012 were described by Kosmann et al. (2013). Wolff et al. (2013) recently registered a new species of Giovanella Bonatto, 2005 and another of Mesembrinella Giglio-Tos, 1983 (Wolff, 2013). There are 29 genera and 99 species recognized distributed in seven Calliphoridae subfamilies: Calliphorinae (three genera and eight species), Chrysomyinae (seven genera and 28 species), Luciliinae (one genus and 17 species), Mesembrinellinae (nine genera and 33 species), Polleniinae (one genus and one species), Rhiniinae (one genus and one species), and Toxotarsinae (seven genera and 11 species).

The Mesembrinellinae is a small group of exclusively Neotropical flies (Toma and Carvalho, 1995), limited to rain forest habitats (Guimarães et al., 1978), dense forests and wetlands, especially at low altitudes (Mello, 1967). Work involving this group has been restricted to description, and no surveys have specifically targeted it (Marinho et al., 2006; Ferraz et al., 2009; Mello et al., 2009; Amat, 2010).

A negative correlation was found between the number of Calliphoridae captured in the Tinguá Biological Reserve and meteorological factors (temperature, relative humidity and precipitation). Two genera of Mesembrinellinae were registered associated with chicken viscera among the 1,987 insects captured (Marinho et al., 2006). Species of Mesembrinellinae are closely linked to natural environments and are considered asynanthropic, in other words, not adapted to human-caused changes, as stated by Mello et al. (2007). Ferraz et al. (2009, 2010b) identified five genera and ten species of a total of 3,378 individuals belonging to this subfamily associated with fish (sardines), representing $39.67 \%$ of the total number of Calliphoridae collected monthly in a year-long study in Rebio-Tinguá, Brazil, in three different sampling sites. Of the 10,444 insects collected by Mello et al. (2009) in this area of Atlantic forest, four genera and six species belonged to the Mesembrinellinae family, and revealed no significant difference in the attractiveness of flies to traps of different colors (black, white, green and red). A faunistic study of asynantropic flies of the Calliphoridae families, in three different landscapes of the Colombian Amazon, registrated two genera of Mesembrinellinae including the first record of Mesembrinella batesi (Aldrich, 1922) in Colombia (Amat, 2010). In the Tijuca National Park, Rio de Janeiro, Brazil, a total of 16,364 Calliphoridae were collected and 17 species were identified, eight of them were species of Mesembrinellinae. In that study species abundance was strongly positively correlated with temperature (Gadelha et al., In press).

Considering the previous statement, it is suggested that the Mesembrinellinae fauna varies in constitution from the edge towards the interior of a forest fragment and that environmental variables may interfere in the capture of these dipterans. Edge effects are consequences of environment fragmentation and promote changes in abiotic and biotic factors that regulate ecosystem. These changes are also noticeable at the level of arthropods, due to their abundance and diversity and the fundamental role they play in forest ecosystems (Ferraz, 2011). However, little is known about the effects of habitat fragmentation on invertebrate populations in general (Didham et al., 1996) which are potential indicators of environmental quality because of their short life cycles and low resistance to environmental imbalances.

Therefore, the objectives of this research were to study the Mesembrinellinae fauna in the Tinguá Biological Reserve in four different sampling sites, to compare the richness, abundance, diversity and population fluctuation 
between the sampling sites, and to analyse the influence of abiotic factors in dipteran capture.

\section{Material and Methods}

\subsection{Study sites}

The Tinguá Biological Reserve (Rebio-Tinguá), a Biosphere conservation unit, is dedicated to the full preservation of the indigenous flora and fauna within its boundaries (Silva, 2000). The reserve is located in Rio de Janeiro and with 24,903ha it is the largest concentration of primary Atlantic Forest in the state (ICMCB, 2010). The reserve houses a very diverse fauna including some endangered species typical of the Atlantic Forest.

The reserve has two cleared conservation corridors for underground pipelines belonging to the Brazilian oil company (Petrobras), which form artificial forest borders that make this fragment potentially subject to edge effects. One of them is the once called Commerce Road. The sampling sites were selected along the Commerce Road, all in the primary Atlantic forest. Site A $\left(22^{\circ} 58.788^{\prime} \mathrm{S}\right.$, $43^{\circ} 43.459^{\prime} \mathrm{W}$ ) was located in the edge and $500 \mathrm{~m}$ from the gate of the reserve; site B $\left(22^{\circ} 58.523^{\prime} \mathrm{S}, 43^{\circ} 44.540^{\prime} \mathrm{W}\right)$ was at $1,000 \mathrm{~m}$ inside de forest and $1,200 \mathrm{~m}$ from the gate; site C $\left(22^{\circ} 58.350^{\prime} \mathrm{S}, 43^{\circ} 44.678^{\prime} \mathrm{W}\right)$ was at $500 \mathrm{~m}$ from edge and $1,700 \mathrm{~m}$ from the gate; and site $\mathrm{D}\left(22^{\circ} 34.865^{\prime} \mathrm{S}\right.$, $43^{\circ} 27.063^{\prime} \mathrm{W}$ ) was at $2,000 \mathrm{~m}$ from the edge and $2,200 \mathrm{~m}$ from the reserve entrance (Figure 1).

\subsection{Sampling of flies}

This study used eight black traps as those described by Mello et al. (2007) and Ferraz and Aguiar-Coelho (2008), each baited with $400 \mathrm{~g}$ of previously frozen sardines and using the same methods described by Ferraz et al. (2009)

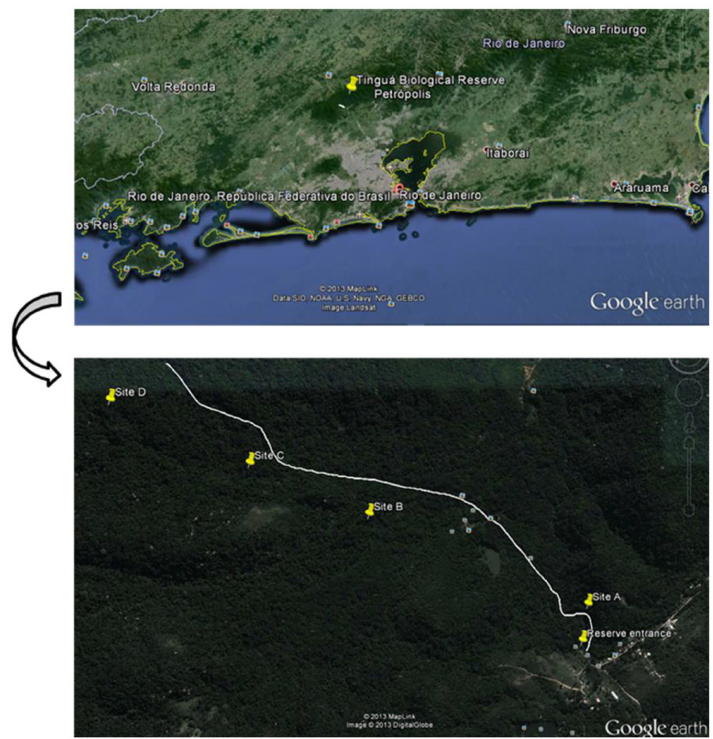

Figure 1. Map showing the state of Rio de Janeiro, marking the location of the Tinguá Biological Reserve and the sampling sites (Source: Google Earth and Garmin GPS, captured at May 2009).
(Figure 2). Samples were collected in August and October 2007, January, April, August, and October 2008, and March and April 2009, to include the four seasons of the year. The insects captured during a period of $48 \mathrm{~h}$ were later were taken to the laboratory, dried under incident light and identified following the taxonomic key of Mello (2003). Specimens were deposited in the Entomological Collection of the Laboratory of Dipteran Studies of the Federal University of the State of Rio de Janeiro (UNIRIO).

The abundance and species richness were recorded, as well as the proportion of males and females. Data for temperature, relative humidity, and rainfall were obtained from the Brazilian National Institute of Meteorology (INMET), at the Rio de Janeiro station (22 $2^{\circ} 53^{\prime} \mathrm{S} 43^{\circ} 11^{\prime} \mathrm{W}$ ). We performed a Pearson correlation analysis, using the program Statistica $\mathbb{C}$, to test for a functional relationship between Mesembrinellinae abundance and richness among the sites, and between these parameters and environmental variables; the $r$ value was classified according to Rodrigues (2006).

The diversity at each site was estimated by the Shannon-Wiener Index, using Dives 2.0 version. Following the principles of Krüger (2006), rare, intermediate and common species were defined. To determine the resident and migrant species at each site, we used the constancy of occurrence formula (Dajoz, 1983; Magurran, 1988, 1989; Zar, 1999; Krebs, 1999). This constancy index

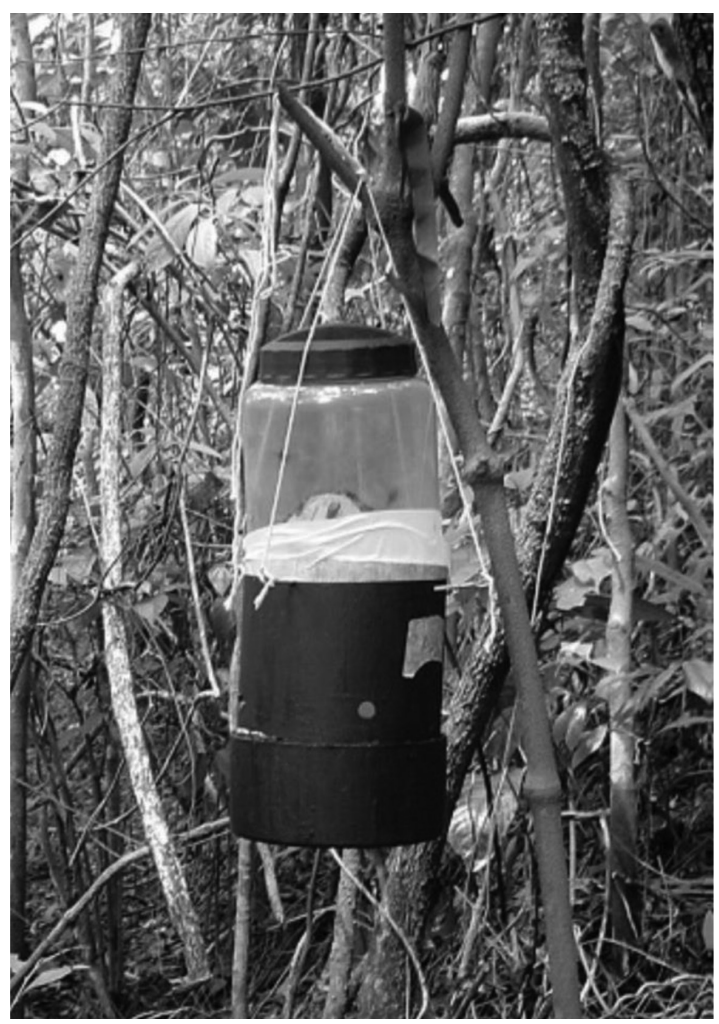

Figure 2. Trap according to the description of Mello et al. (2007) and Ferraz and Aguiar-Coelho (2008), used to capture Mesembrinellinae dipterans. 
classifies species as accidental, accessory, and constant. The similarity among the populations of Mesembrinellinae at the different collection sites was determined by the Jaccard coefficient (Dajoz, 1983; Magurran, 1991). Most species collected were compared using cluster analysis to determine the grouping as a function of habitat type (Zar, 1999) and season, by a dendogram using Euclidean distance, with StatisticaC.

\section{Results}

From winter 2007 through autumn 2009, a total of 4,240 flies were captured: 3,785 (89.27\%) Calliphoridae and $455(10.73 \%)$ Sarcophagidae. Among the Calliphoridae, $2,150(56.80 \%)$ belonged to the subfamily Mesembrinellinae, including four genera and 10 species (Table 1). The most abundant species was Laneela nigripes Guimarães, 1977 with $64.19 \%$, followed by Mesembrinella bellardiana Aldrich, 1922 with $21.86 \%$. More females (80\%) than males $(20 \%)$ were captured, both overall and for each species. The seasonal distributions of the four most abundant species collected in Rebio-Tinguá are presented according to collection sites in Figure 3. Mainly, L. nigripes increased in winter 2008, except at site B, where it was more numerous in spring 2008. The largest catches of Eumesmbrinella cyaneicincta (Surcouf, 1919) did not show a strong seasonal pattern, whereas $M$. bellardiana has peaks in spring 2007, summer 2008-2009 and autumn 2009. The dendrogram indicating the similarity of the six species collected most often during the study period is shown in Figure 4 and it indicated the existence of several groups. Laneela nigripes appeared separate from the others, since it was the most abundant species at site C.
The abundance of Mesembrinellinae was strongly and positively correlated with relative humidity $(\mathrm{r}=0.432)$, weakly and negatively with temperature $(\mathrm{r}=-0.308)$, and showed no significant correlation with precipitation $(\mathrm{r}=0.190)$ (Figure 5). Species richness was negatively and weakly correlated with temperature $(\mathrm{r}=-0.368)$ and precipitation $(r=0.398)$ and showed no significant relationship with relative humidity $(\mathrm{r}=0.104)$.

The populations were similar among the sites, according to the Jaccard coefficients. Site A was considered similar to the others $(\mathrm{A} \times \mathrm{B}=55.6 \% \mathrm{~A} \times \mathrm{C}=40.0 \% ; \mathrm{A} \times \mathrm{D}=50.0 \%)$ and the relationships between $\mathrm{B} \times \mathrm{C}(71.4 \%), \mathrm{B} \times \mathrm{D}(85.7 \%)$ and $\mathrm{C} \times \mathrm{D}(62.5 \%)$ were very similar.

Site $\mathrm{B}$ had the highest number of specimens collected over the four sampling sites, followed by sites C, D, and A. The absolute values of the species collected at each site and their percentages are given in Table 1 .

Comparing the abundance with richness in each of the sites, there was no correlation at sites $\mathrm{A}(\mathrm{r}=-0.174)$ and $\mathrm{D}$ $(\mathrm{r}=0.110)$, a weakly positive correlation at $\mathrm{C}(\mathrm{r}=0.387)$ and a substantially positive correlation at $\mathrm{B}(\mathrm{r}=0.467)$. Diversity was higher at sites $B\left(H^{\prime}=0.525\right)$ and $A\left(H^{\prime}=0.520\right)$ than at $\mathrm{D}\left(\mathrm{H}^{\prime}=0.339\right)$ and $\mathrm{C}\left(\mathrm{H}^{\prime}=0.269\right)$. Nevertheless, site $\mathrm{A}$ showed the highest species richness (eight species) and the lowest abundance. Overall, the differences in species richness among the sites are small (8:6:6:7). The highest diversity was found in spring 2007 , at site $A\left(H^{\prime}=0.608\right)$, and the lowest in summer 2009 , at site $\mathrm{D}\left(\mathrm{H}^{\prime}=0.105\right)$.

Eumesembrinella cyaneicincta, L. nigripes, M. bellardiana, and Mesembrinella semihyalina Mello, 1967 were common and constant. Of these, only E. cyaneicincta showed a strong negative correlation with temperature, and M. semihyalina

Table 1. Absolute and relative abundances of species of the subfamily Mesembrinellinae captured at each site in the Tinguá Biological Reserve, state of Rio de Janeiro, from winter 2007 through autumn 2009.

\begin{tabular}{|c|c|c|c|c|c|c|c|c|c|}
\hline $\begin{array}{c}\text { Species } \\
\end{array}$ & $\mathbf{A}$ & $\%$ & B & $\%$ & $\mathbf{C}$ & $\%$ & D & $\%$ & TOTAL \\
\hline $\begin{array}{l}\text { Eumesembrinella } \\
\text { besnoiti }\end{array}$ & 1 & 0.34 & 0 & 0.00 & 1 & 0.16 & 0 & 0.00 & 2 \\
\hline $\begin{array}{l}\text { Eumesembrinella } \\
\text { cyaneicincta }\end{array}$ & 23 & 7.85 & 94 & 10.99 & 18 & 2.80 & 6 & 1.68 & 141 \\
\hline $\begin{array}{l}\text { Eumesembrinella } \\
\text { quadrilineata }\end{array}$ & 1 & 0.34 & 0 & 0.00 & 0 & 0.00 & 0 & 0.00 & 1 \\
\hline $\begin{array}{l}\text { Huascaromusca } \\
\text { aeneiventris }\end{array}$ & 0 & 0.00 & 0 & 0.00 & 0 & 0.00 & 2 & 0.28 & 2 \\
\hline $\begin{array}{l}\text { Huascaromusca } \\
\text { purpurata }\end{array}$ & 0 & 0.00 & 2 & 0.23 & 1 & 0.16 & 1 & 0.28 & 4 \\
\hline Laneela nigripes & 166 & 56.66 & 403 & 47.13 & 535 & 83.07 & 276 & 77.09 & 1380 \\
\hline $\begin{array}{l}\text { Mesembrinella } \\
\text { batesi }\end{array}$ & 1 & 0.34 & 0 & 0.00 & 0 & 0.00 & 0 & 0.00 & 1 \\
\hline $\begin{array}{l}\text { Mesembrinella } \\
\text { bellardiana }\end{array}$ & 65 & 22.18 & 285 & 33.33 & 72 & 11.18 & 48 & 13.41 & 470 \\
\hline $\begin{array}{l}\text { Mesembrinella } \\
\text { bicolor }\end{array}$ & 2 & 0.68 & 6 & 0.70 & 0 & 0.00 & 1 & 0.28 & 9 \\
\hline $\begin{array}{l}\text { Mesembrinella } \\
\text { semihyalina }\end{array}$ & 34 & 11.60 & 65 & 7.60 & 17 & 2.64 & 24 & 6.70 & 140 \\
\hline TOTAL & 293 & & 855 & & 644 & & 358 & & 2150 \\
\hline
\end{tabular}


Site A

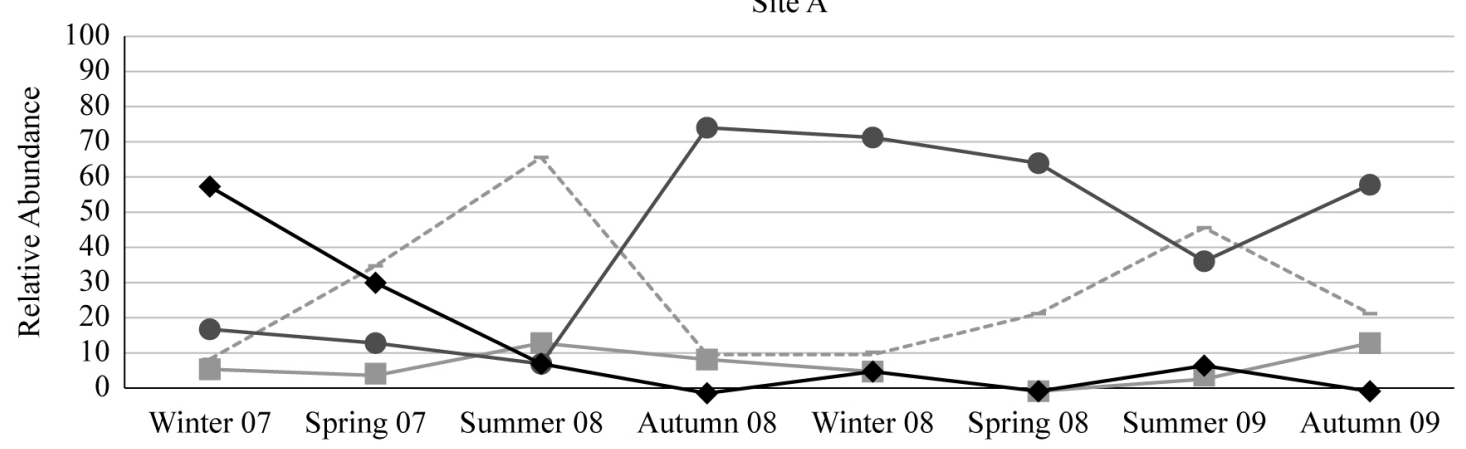

Site B

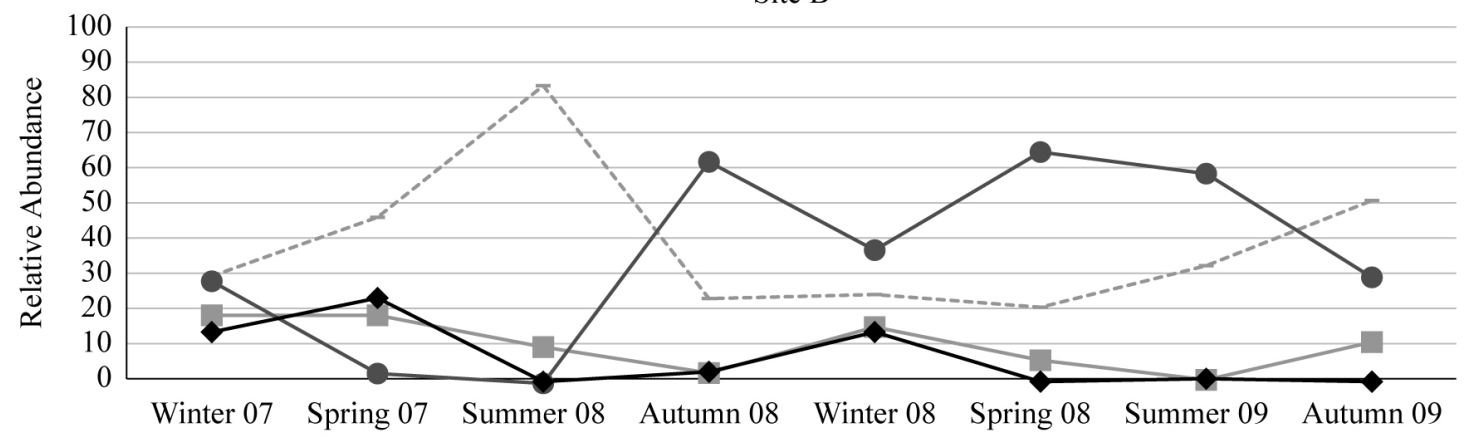

Site C

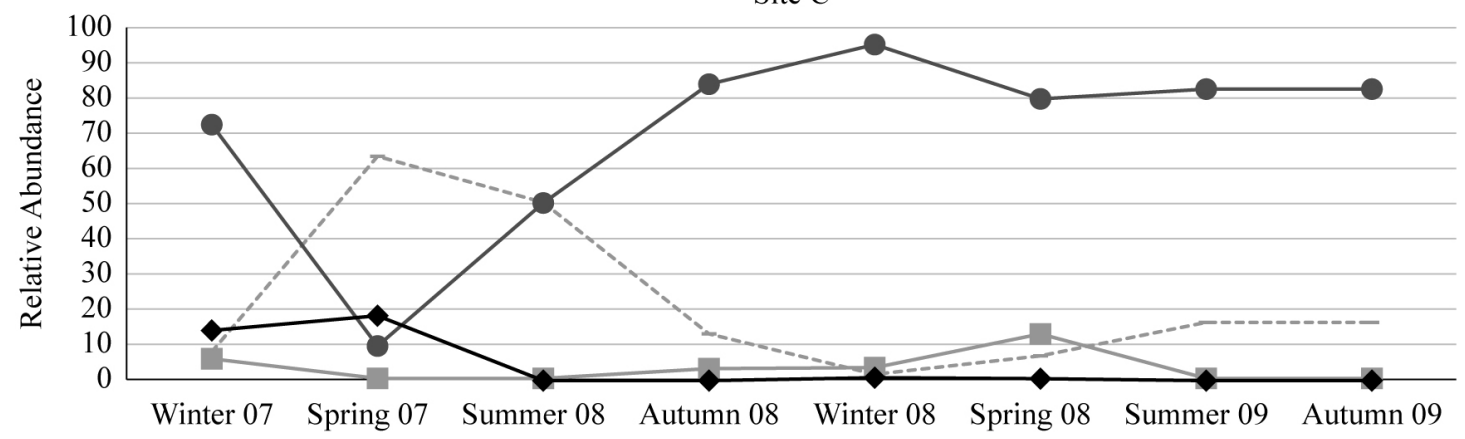

Site D

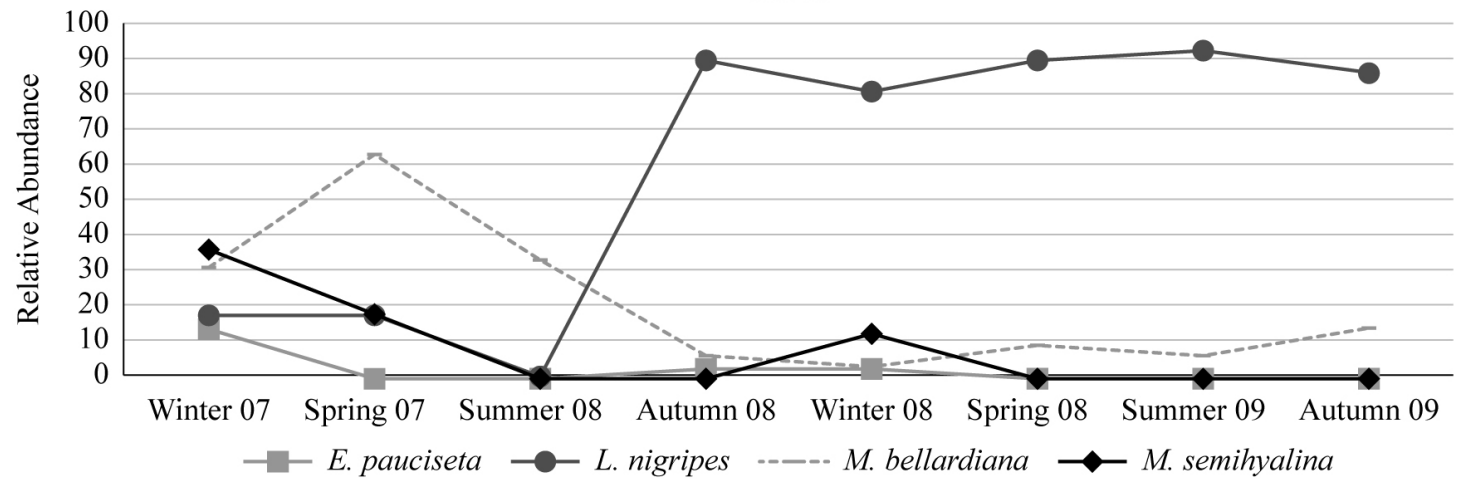

Figure 3. Seasonal proportion of the four most abundant species of Mesembrinellinae caught in the Tinguá Biological Reserve, state of Rio de Janeiro, at the collection sites.

showed a weak positive correlation $(\mathrm{r}=0.729, \mathrm{r}=0.140$, $\mathrm{r}=0.160, \mathrm{r}=0.422)$. Intermediate and accessory species were Mesembrinella bicolor (Fabricius, 1805) and Huascaromusca purpurata (Aldrich, 1922), whereas
Eumesembrinella besnoiti (Seguy, 1925) was classified as rare and accessory. Eumesembrinella quadrilineata (Fabricius, 1805), Mesembrinella batesi Aldrich, 1922, and Huascaromusca aeneiventris (Wiedmann, 1830) were 


\section{Tree Diagram for 6 Cases \\ Single Linkage \\ Euclidean distances}

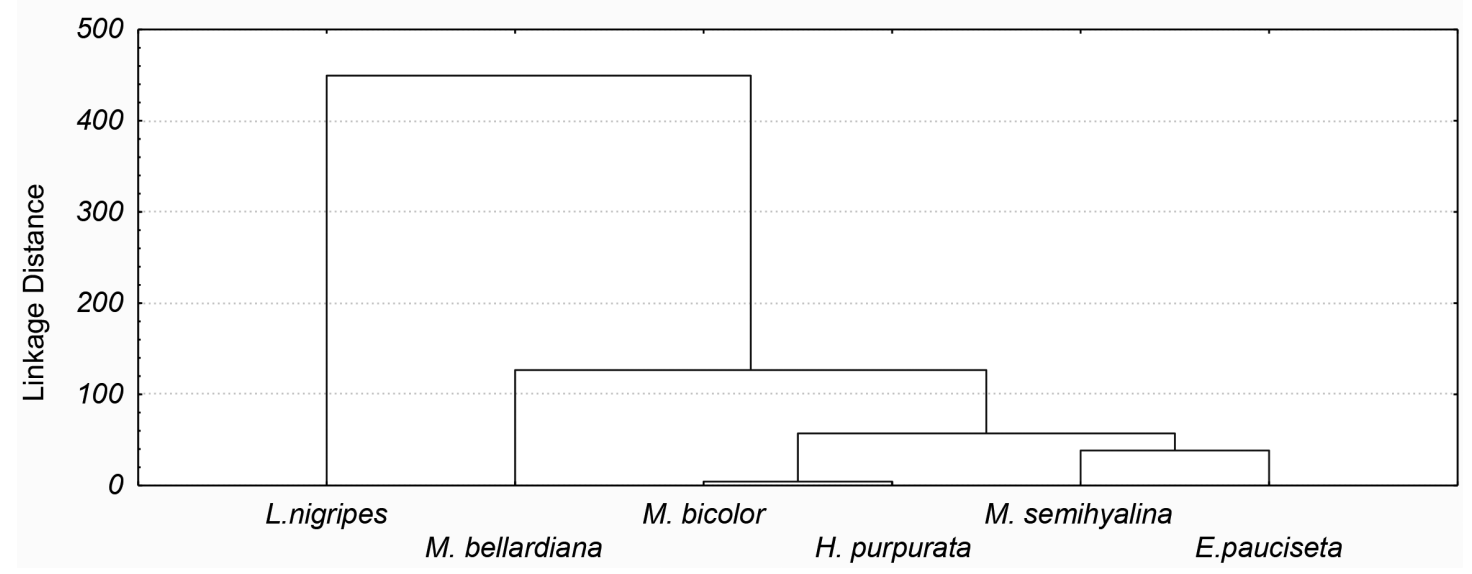

Figure 4. Dendogram showing similarities among the six most-collected species of Mesembrinellinae in the Tinguá Biological Reserve from winter 2007 through autumn 2009.

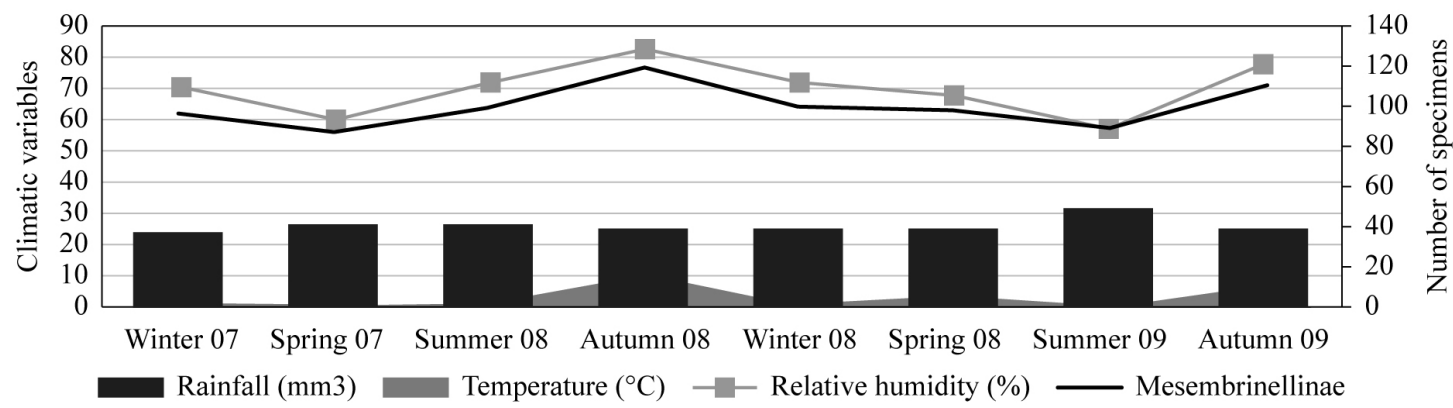

Figure 5. Abundance of Mesembrinellinae flies captured with sardines baited traps, and environmental variables (temperature, relative humidity, and precipitation) in the Tinguá Biological Reserve, state of Rio de Janeiro.

considered rare and accidental. Eumesembrinella benoisti and $H$. aeneiventris were classified as doubletons, and $E$. quadrilineata and $M$. batesi as singletons.

\section{Discussion}

\subsection{General aspects of Mesembrinellinae distribution}

In the Tinguá Biological Reserve (Rebio Tinguá), female calliphorids strongly predominated over males in the samples. Similar differences were noted in captures of Calliphoridae by Paraluppi and Castellón (1994) and Marinho et al. (2006). It is likely that this disproportion results from a greater activity of females searching for oviposition or larviposition substrates of animal origin such as meat or decaying offal. Avancini (1988) suggested that the larger number of females results from the requirement for a substrate for feeding, since the females of Calliphoridae need protein for ovarian development. Ferraz et al. (2010b) also found a higher capture rate of female calliphorids in Rebio Tinguá, but when individual species were assessed, $E$. besnoiti and $H$. purpurata did not follow this pattern, possibly because of inadequate sampling, capturing a small number of specimens.

There are nine genera and 33 species of Mesembrinellinae in the Neotropical region in the Américas south of Mexico (Kosmann et al., 2013). Sousa (2008) recorded 356 mesembrinellines including five species, in traps in Amazonia; the species composition in the Amazon forest biome may differ from that in the Atlantic Forest. Studies conducted by Marinho et al. (2006), Ferraz et al. (2009, 2010a), Mello et al. (2009), Amat (2010), Cabrini et al. (2013) and Gadelha et al. (In press) revealed the occurrence of an abundant fauna of Mesembrinellinae in the Atlantic Forest.

The choice of bait may have been crucial to ascertain the diversity of Mesembrinellinae. This supposition is reinforced by the fact that Marinho et al. (2006), who used chicken viscera, did not record L. nigripes at Rebio-Tinguá. In contrast, in this study as well as in those of Mello et al. (2007) and Ferraz et al. (2009), this species was highly important and was considered constant from sampling using sardines to attract the flies. 


\subsection{The influence of fragmentation and edge effects}

The fragmented habitat studied has been established for several decades and it is continually maintained by the passage of vehicles. The Commerce Road in Rebio Tinguá is a cleared corridor used by the Brazilian oil company (Petrobras), which forms artificial forest borders that make this fragment potentially subject to edge effects. This fragmentation may cause border effects on the fly populations (Ferraz et al., 2009). Many studies have been developed to determine how edge effects act on forest fauna. Among them we can mention Ribas et al. (2005), with ants and crikets; McGeoch and Gaston (2000), Ferraz et al. (2010a), Copatti and Gasparetto (2012), Penariol and Madi-Ravazzi (2013), and Cabrini et al. (2013) with Diptera. The latest analysed richness and composition of Calliphoridae fauna in an Atlantic Forest fragment, and indicated Mesmebinellinae as a sort of bioindicator.

Furusawa and Cassino (2006) found greater abundance and diversity of Calliphoridae in the forest edge, in contrast to this study that found greater diversity and abundance at the site located $1,000 \mathrm{~m}$ inside the forest (site B). This is an intermediate site and the local floristic composition may affect the distribution and habitat occupancy.

Jaccard's coefficient was used to compare the similarities among populations at the different sites. This coefficient rarely exceeds $60 \%$, and in the present study the comparisons between sites $\mathrm{B} \times \mathrm{C}, \mathrm{B} \times \mathrm{D}$ and $\mathrm{C} \times \mathrm{D}$ were higher than this percentage, indicating that the populations are very similar. According to Ferraz et al. (2010a), who also found high similarity among sites, this can be explained by the proximity and similarity in habitat among the sites. These similarities between populations at different sampling sites probably reflect an unspoiled environment where the flies are not subject to edge effects, especially at $500 \mathrm{~m}$ or more into the forest.

The relationship of abundance and richness to environmental variables may be different in Mesembrinellinae compared to other Calliphoridae, since species of this subfamily appear to have different habits and different geographical and seasonal distributions.

Species such as E. besnoiti, E. quadrilineata, $H$. aeneiventris, and $M$. batesi, which were considered rare in this study, may have their distributions limited by low population densities. Turner (1996) pointed out that rare species with small distribution areas or species that require very large or specialized habitats may be more susceptible to the effects of habitat fragmentation. Thomazini and Thomazini (2000) added that in tropical forests, most species are susceptible to extinction because they occur in low densities and participate in narrow, complex ecological relationships with other species. Studies carried out by other authors (Turner, 1996; Thomazini and Thomazini, 2000) may help to justify these rare species distributions which were probably influenced by the modification that the edge effects did in these habitat. Thus, when a forest is fragmented, many species disappeared or become rarer while others are unaffected or even become more abundant. In general, the species that are the most vulnerable to the effects of habitat fragmentation are those that need extensive areas of life as well, are negatively affected by edge effects, or do not adapt to the habitat matrix. That is, they are forest expert, which generally need large areas of undisturbed forest. Meanwhile, the species that are resistant to the effects of fragmentation usually have opposite characteristics (Laurance and Vasconcelos, 2009).

This should serve as a warning in regard to the monitoring of species of Mesembrinellinae over the years, especially in view of the study of Ferraz et al. (2010a), in which E. randa, E. quadrilineata, E. besnoiti, and H. purpurata were found in low densities, in addition to the rare species cited in the present study.

The ecological relationships that involve rare species in tropical forests may be affected by the introduction of exotic species (invasive) which upsets the delicate balance of the ecosystem and ecological relationships of the native species (Furusawa and Cassino, 2006). In previous studies in this reserve we found a dominance of the exotic species Chrysomya albiceps (Wiedemann, 1819) in the border area and the presence of this species and Chrysomya megacephala (Fabricius, 1805) in all studied sites, so they may influence the native species distribution (Ferraz et al., 2009). Invasive exotic species may contribute to the displacement of native species and even to their extinction, in the event of competition for the same ecological niche. Riback and Godoy (2008) discuss the implications of $C$. albiceps bionomic variations for that species population dinamics and believe that their results explain at least in part the success of the species following the occurrence of the biological invasion.

\subsection{Species distribution: edge effects $\times$ seasonality}

The population of L. nigripes peaked in September 2002, May and June 2003, and September 2004 in the survey of Mello et al. (2007), with a total of 1,722 specimens collected over three years. Ferraz et al. (2010b) reported that the species showed a peak in February 2007 and lowest abundance in December 2006, based on 1,641 specimens. In the current study, L. nigripes was constant at all sampling sites, peaking in winter 2008 and with a lower catch in the summer of that year. This observation differs from the findings of Ferraz et al. (2010b), but agrees with those of Mello et al. (2007). It was most often captured at the site located $500 \mathrm{~m}$ from the edge, where it was dominant, in both our studies (Ferraz et al., 2010b) as showed on the dendogram. This species is adapted to the environmental conditions presented in the intermediate place from the edge and the interior. In the current study, L. nigripes was prominent, comprising $64.19 \%$ of the total of 1,380 specimens from eight samples.

Ferraz et al. (2010b) found that M. bellardiana was more abundant in September 2006 and less so in July 2006. In contrast, in the current study this species was caught mostly in autumn 2009 and showed its lowest abundance in summer 2008. It was constant at all sampling sites, with the highest figures at B, demonstrating that the edge effects limit its distribution as far as $500 \mathrm{~m}$. Ferraz et al. (2010a) found a predominance of this species with $M$. semihyalina 
in the forest interior, as also observed in our study, where these two species predominated in the area $1,000 \mathrm{~m}$ inside the forest ( site B). In concordance, D'Almeida and Lopes (1983) found that the synanthropic index of this species in metropolitan Rio de Janeiro was -100 .

Mesembrinella semihyalina was most abundant in winter 2007, and did not occur in autumn 2009. It was found at all sites, with the largest sample at B, and was considered constant. Ferraz et al. (2010a) reported it as the only species of Calliphoridae occurring exclusively at the site $1,000 \mathrm{~m}$ inside the forest, indicating its asynanthropic character and the influence of edge effects. In the current study and in the previous one (Ferraz et al., 2010b), this species showed a negative correlation with precipitation, i.e., it is more abundant during periods of low rainfall. In Brazil, M. semihyalina occurs in the states of Espírito Santo and Rio de Janeiro (Toma and Carvalho, 1995).

Only a few specimens of $E$. benoisti, E. quadrilineata, and $H$. purpurata were captured, as also observed by Ferraz et al. (2010b), indicating the difficulty of capturing these species and assessing their distribution. These species were not found by Mello et al. (2007).

Huascaromusca aeneiventris was represented by only two specimens in the summer 2008, at 2,000m from the edge. In our previous survey, we did not collect $H$. aeneiventris during summer, and most individuals were found $1,000 \mathrm{~m}$ from the edge (Ferraz et al., 2010b). Therefore we cannot assess the correlation with the seasons but its relationship to the edge effects is clear, indicating it is distributed mainly inside the forest.

\section{Conclusion}

The Mesmebrinellinae family is represented by ten species in the Tinguá Biological Reserve. These flies occurred from the edge up to $2,000 \mathrm{~m}$ inside the forest. The first site (site A) was the most influenced by the edge effects, showing less abundance of forest flies (Mesembrinellinae) and it presented differences in the population related to the other sites studied, while the greatest abundance was obtained from the site at $1,000 \mathrm{~m}$ inside the forest (site B). The abundance of Mesembrinellinae was positively correlated with relative humidity and negatively with temperature. Species richness was negatively correlated with temperature and precipitation.

\section{Acknowledgements}

The authors thank CAPES, CNPq, FINEP, and UNIRIO for grants in support of the study. We thank Janet Reid for her English revision. We appreciate the help of the staff of the Tinguá Biological Reserve (Nova Iguaçu office), IBAMA for the study permit.

\section{References}

AMAT, E., 2010. Notes on necrophagous flies (Diptera: Calyptratae) associated to fish carrion in Colombian Amazon. Acta Amazonica, vol. 40, no. 2, pp. 397-400. http://dx.doi.org/10.1590/S004459672010000200018 .
AVANCINI, R.M.P., 1988. The influence of non-protein diet on ovarian development in Chrysomya putoria (Diptera, Calliphoridae). Revista Brasileira de Entomologia, vol. 32, no. 2, pp. 103-105.

CABRINI, I., GRELLA, M.D., ANDRADE, C.F.S. and THYSSEN, P.J., 2013. Richness and composition of Calliphoridae in an Atlantic Forest fragment: implication for the use of dipteran species as bioindicators. Biodiversity and Conservation, vol. 22, no. 11, pp. 2635-2643. http://dx.doi.org/10.1007/s10531-013-0545-x.

COPATTI, C.E. and GASPARETTO, F.M., 2012. Diversidade de insetos em diferentes tipos de borda em um fragmento de Floresta Ombrófila Mista. Revista Biociências, vol. 18, pp. 32-40.

D'ALMEIDA, J.M. and LOPES, H.S., 1983. Sinantropia de dípteros muscóides (Calliphoridae) no Estado do Rio de Janeiro. Arquivos da Universidade Federal Rural do Rio de Janeiro, vol. 6 , no. 1, pp. 39-48.

DAJOZ, R., 1983. Ecologia geral. 4th ed. Petrópolis: Vozes. 474 p.

DIDHAM, R.K., GHAZOUL, J., STORK, N.E. and DAVIS, A.J., 1996. Insects in fragmented forest: a functional approach. Trends in Ecology \& Evolution, vol. 11, no. 6, pp. 255-260. http://dx.doi. org/10.1016/0169-5347(96)20047-3. PMid:21237834.

FERRAZ, A.C.P., 2011. Efeitos de borda em florestas tropicais sobre artrópodes, com ênfase nos dípteros ciclorrafos. Oecologia Australis, vol. 15, no. 2, pp. 189-198. http://dx.doi.org/10.4257/ oeco.2011.1502.01

FERRAZ, A.C. and AGUIAR-COELHO, V.M., 2008. Desenvolvimento e avaliação de novas metodologias para testar a atratividade de Chrysomya megacephala (Fabricius) (Diptera: Calliphoridae) a estímulo visual por cores em condições laboratoriais. Neotropical Entomology, vol. 37, no. 3, pp. 334-337. http://dx.doi.org/10.1590/ S1519-566X2008000300014. PMid:18641906.

FERRAZ, A.C.P., GADELHA, B.Q. and AGUIAR-COELHO, V.M., 2009. Análise faunística de califorídeos (Diptera) da reserva biológica do Tinguá, Nova Iguaçu, Rio de Janeiro. Revista Brasileira de Entomologia, vol. 53, no. 4, pp. 620-628. http:// dx.doi.org/10.1590/S0085-56262009000400012.

FERRAZ, A.C.P., GADELHA, B.Q., QUEIROZ, M.M.C., MOYABORJA, G.E. and AGUIAR-COELHO, V.M., 2010a. Efeitos da fragmentação florestal sobre a dipterofauna (Calliphoridae) na Reserva Biológica do Tinguá, Nova Iguaçu, RJ. Brazilian Journal of Biology $=$ Revista Brasileira de Biologia, vol. 70, no. 1, pp. 55-63. http://dx.doi.org/10.1590/S1519-69842010000100009.

FERRAZ, A.C.P., GADELHA, B.Q. and AGUIAR-COELHO, V.M., 2010b. Influência climática e antrópica na abundância e riqueza de Calliphoridae (Diptera) em fragmento florestal da Reserva Biológica do Tinguá, Nova Iguaçu, Brasil. Neotropical Entomology, vol. 39, no. 4, pp. 476-485. http://dx.doi.org/10.1590/ S1519-566X2010000400004. PMid:20877981.

FORMAN, R.T.T. and GORDON, M., 1986. Landscape ecology. New York: John Wiley. 619 p.

FURUSAWA, G.P. and CASSINO, P.C.R., 2006. Ocorrência e distribuição de Calliphoridae (Diptera: Oestroidea) em um fragmento de mata secundária no município de Paulo de Frontin, Médio Paraíba, RJ. Revista de Biologia e Ciências da Terra, vol. 6 , no. 1 , pp. 152-164.

GADELHA, B.Q., FERRAZ, A.C.P. and AGUIAR-COELHO, V.M., 2009. A importância dos mesembrinelíneos (Diptera: Calliphoridae) e seu potencial como indicadores de preservação ambiental. Oecologia Brasiliensis, vol. 13, no. 4, pp. 660-664. 
GADELHA, B.Q., RIBEIRO, A.C., AGUIAR, V.M. and MELLOPATIU, C. A. In press. Edge effects on the blowfly fauna (Diptera, Calliphoridae) of the Parque Nacional da Tijuca, Rio de Janeiro, Brazil. Brazilian Journal of Biology $=$ Revista Brasileira de Biologia, vol. 76, no. 2.

GREENBERG, B. and SZYSKA, M.L., 1984. Immatures stages biology of fifteen species of Peruvian Calliphoridae (Diptera). Annals of the Entomological Society of America, vol. 77, no. 5, pp. 488-517. http://dx.doi.org/10.1093/aesa/77.5.488.

GUIMARÃES, J.H., PRADO, A.P. and LINHARES, A.X., 1978. Three newly introduced blowfly species in southern Brazil (Diptera, Calliphoridae). Revista Brasileira de Entomologia, vol. 22 , pp. $53-60$.

INSTITUTO CHICO MENDES DE CONSERVAÇÃO DA BIODIVERSIDADE - ICMCBio, 2010 [viewed 13 January 2013]. Unidade: reserva biológica do Tinguá [online]. Brasília. Available from: http://www.icmbio.gov.br/portal/biodiversidade/ unidades-de-conservacao/biomas-brasileiros.html

KOSMANN, C., MELLO, R.P., HARTERREITEN-SOUZA, E.S. and PUJOL-LUZ, J.R., 2013. A list of current valid blow fly names (Diptera: Calliphoridae) in the Americas South of Mexico with key to the brazilian species. EntomoBrasilis, vol. 6, no. 1, pp. 74-85. http://dx.doi.org/10.12741/ebrasilis.v6i1.266.

KREBS, C.J., 1999. Ecological methodology. New York: Addison Wesley Longman. $620 \mathrm{p}$.

KRÜGER, R.F., 2006. Análise da riqueza e da estrutura das assembléias de Muscidae (Diptera) no bioma Campos Sulinos, Rio Grande do Sul, Brasil. Curitiba: Universidade Federal do Paraná, 139 p. PhD Thesis.

KUTTY, S.N., PAPE, T., WIEGMANN, B.M. and MEIER, R., 2010. Molecular phylogeny of the Calyptratae (Diptera: Cyclorrhapha) with an emphasis on the superfamily Oestroidea and the position of Mystacinobiidae and McAlpine's fly. Systematic Entomology, vol. 35 , no. 4 , pp. 614-635. http://dx.doi.org/10.1111/j.13653113.2010.00536.x.

LAURANCE, W.F. and VASCONCELOS, H.L., 2009. Conseqüências ecológicas da fragmentação florestal na Amazônia. Oecologia Brasiliensis, vol. 13, no. 3, pp. 434-451. http://dx.doi.org/10.4257/ oeco.2009.1303.03.

MAGURRAN, A.E., 1988. Ecological diversity and its measurement. New Jersey: Princeton University Press. 179 p.

MAGURRAN, A.E., 1989. Diversidad ecológica y su medicion. Barcelona: Ediciones Vedrà. 200 p.

MAGURRAN, A.E., 1991. Ecological diversity and its measurement. New York: Chapman \& Hall. 179 p.

MARINHO, C.R., BARBOSA, L.S., AZEVEDO, A.C.G., QUEIROZ, M.M.C., VALGODE, M.A. and AGUIAR-COELHO, V.M., 2006. Diversity of Calliphoridae (Diptera) in Brazil's Tinguá Biological Reserve. Brazilian Journal of Biology $=$ Revista Brasileira de Biologia, vol. 66, no. 1A, pp. 95-100. http://dx.doi.org/10.1590/ S1519-69842006000100012. PMid:16680310.

MARTOS, H.L. and MAIA, N.B., 1997. Indicadores ambientais. Sorocaba: USP. 266 p.

MCGEOCH, M.A. and GASTON, K.J., 2000. Edge effects on the prevalence and mortality factors of Phytomyza ilicis (Diptera,
Agromyzidae) in a suburban woodland. Ecology Letters, vol. 3, no. 1, pp. 23-29. http://dx.doi.org/10.1046/j.1461-0248.2000.00114.x.

MELLO, R.P., 1967. Contribuição ao estudo dos Mesembrinellinae sul-americanos (Diptera, Calliphoridae). Studia Entomologica, vol. 10 , pp. 1-80.

MELLO, R.P., 2003. Chave para a identificação das formas adultas das espécies da família Calliphoridae (Diptera, Brachycera, Cyclorrhapha) encontradas no Brasil. Entomologia y Vectores, vol. 10 , no. 2 , pp. $255-268$.

MELLO, R.S., QUEIROZ, M.M.C. and AGUIAR-COELHO, V.M., 2007. Population fluctuations of calliphorid species (Diptera, Calliphoridae) in the Biological Reserve of Tinguá, state of Rio de Janeiro, Brazil. Iheringia: Série Zoologia, vol. 97, no. 4, pp. 1-5. http://dx.doi.org/10.1590/S0073-47212007000400019.

MELLO, R.S., QUEIROZ, M.M.C., NUNES-FREITAS, A.F. and AGUIAR-COELHO, V.M., 2009. Calliphorid fly (Diptera, Calliphoridae) attraction to different coloredtraps in the Tingua Biological Reserve, Rio de Janeiro, Brazil. Iheringia: Série Zoologia, vol. 99, no. 4, pp. 426-430. http://dx.doi.org/10.1590/ S0073-47212009000400013.

PARALUPPI, N.D. and CASTELLÓN, E.G., 1994. Calliphoridae (Diptera) em Manaus: I. Levantamento taxonômico e sazonalidade. Revista Brasileira de Entomologia, vol. 38, pp. 661-668.

PENARIOL, L.V. and MADI-RAVAZZI, L., 2013. Edge-interior differences in the species richness and abundance of Drosophilids in a semideciduous forest fragment. SpringerPlus, vol. 2, no. 1, pp. 114. http://dx.doi.org/10.1186/2193-1801-2-114. PMid:23556146.

PRADO, A.P. and GUIMARÃES, J.H., 1982. Estado atual da distribuição e dispersão das espécies do gênero Chrysomya R-D na região neotropical (Diptera: Calliphoridae). Revista Brasileira de Entomologia, vol. 26, no. 3-4, pp. 225-231.

RIBACK, T.I. and GODOY, W.A., 2008. Fecundity, body size and population dynamics of Chrysomya albiceps (Wiedemann, 1819) (Diptera: Calliphoridae). Brazilian Journal of Biology $=$ Revista Brasileira de Biologia, vol. 68, no. 1, pp. 123-128. http:// dx.doi.org/10.1590/S1519-69842008000100017. PMid:18470386.

RIBAS, C.R., SOBRINHO, T.G., SCHOEREDER, J.H., SPERBER, C.F., LOPES-ANDRADE, C. and SOARES, S.M., 2005. How large is large enough for insects? Forest fragmentation effects at three spatial scales. Acta Oecologica, vol. 27, no. 1, pp. 31-41. http://dx.doi.org/10.1016/j.actao.2004.08.008.

RODRIGUES, W.C., 2006 [viewed 15 January 2013]. Estatística ambiental: planejamento e gestão ambiental Latu Sensu [online]. 3rd ed. Vassouras: Universidade Severino Sombra. Available from: http://www.ebras.bio.br/autor/artigos/estat_ambiental.pdf

ROGNES, K., 2005. The Calliphoridae (Blowflies) (Diptera: Oestroidea) are not a monophyletic group. Cladistics, vol. 13, no. 1-2, pp. 27-66. http://dx.doi.org/10.1111/j.1096-0031.1997. tb00240.x.

SILVA, J.A., CARVALHO-FILHO, F.S., ESPOSITO, M.C. and REIS, G.A., 2012. First record of Chrysomya rufifacies (Macquart) (Diptera, Calliphoridae) from Brazil. Revista Brasileira de Entomologia, vol. 56, no. 1, pp. 115-118. http://dx.doi.org/10.1590/ S0085-56262012000100019.

SILVA, L.P., 2000 [viewed 4 January 2013]. Um pouco sobre a reserva biológica do Tinguá [online]. Nova Iguaçu: Sampa Bikers. Available from: http://inema.com.br/mat/idmat001103.htm 
SOUSA, J.R.P., 2008. A fauna de califorídeos e sarcofagídeos (Insecta, Diptera) das matas e clareiras com diferentes coberturas vegetais da base de extração petrolifera, Bacia do Rio Urucu, Coari, Amazonas. Belém: Museu Paraense Emílio Goeldi, Universidade Federal do Pará, 116 p. Masters Dissertation.

THOMAZINI, M.J. and THOMAZINI, A.P.B.W., 2000 [viewed 15 January 2013]. A fragmentação florestal e a diversidade de insetos nas florestas tropicais úmidas [online]. Rio Branco: Embrapa. Available from: http://www.cpafac.embrapa.br/pdf/doc57.pdf

TOMA, R. and CARVALHO, C.J.B., 1995. Estudo filogenético de Mesembrinellinae com ênfase no gênero Eumesembrinella Towsend (Diptera: Calliphoridae). Revista Brasileira de Zoologia, vol. 12, no. 1, pp. 127-144. http://dx.doi.org/10.1590/S010181751995000100014 .
TURNER, I.M., 1996. Species loss in fragments of tropical rain forest: a review of the evidence. Journal of Applied Ecology, vol. 33, no. 2, pp. 200-209. http://dx.doi.org/10.2307/2404743.

WOLFF, M., 2013. A new species of Mesembrinella (Diptera: Calliphoridae: Mesembrinellinae) from Colombia. Revista Colombiana de Entomologia, vol. 39, no. 1, pp. 120-124.

WOLFF, M., RAMOS-PASTRANA, Y. and PUJOL-LUZ, J.R., 2013. A new species of Giovanella Bonatto (Diptera, Calliphoridae, Mesembrinellinae) from Colombia. Revista Brasileira de Entomologia, vol. 57, no. 2, pp. 129-132. http:// dx.doi.org/10.1590/S0085-56262013005000013.

ZAR, J.H., 1999. Biostatistical analysis. 4th ed. New Jersey: Prentice Hall. 663 p. 